\title{
Sowing methods for successful pasture establishment - a review
}

\author{
E.R. THOM ${ }^{1}$, T.J. FRASER ${ }^{2}$ and D.E. HUME ${ }^{3}$ \\ ${ }^{1}$ DairyNZ, Private Bag 3221, Hamilton 3240 \\ ${ }^{2}$ AgResearch Lincoln, Private Bag 4749, Christchurch 8140 \\ ${ }^{3}$ AgResearch Grasslands, Private Bag 11008, Palmerston North 4442
}

errol.thom@dairynz.co.nz

\begin{abstract}
Methods of achieving successful pasture establishment have been broadened over the last 50 years by the introduction of no-tillage technologies, providing a viable alternative to cultivation. Parallel developments in drill technologies for seed and fertiliser placement, and methods to control competition from the existing pasture have ensured the success of no-tillage methods. This review focuses on the effects of the establishment method on seedling growth over the establishment period, defined for the purposes of this paper as the year after sowing. Undersowing existing pasture is the establishment method least likely to provide a suitable environment for seedling growth and development. New pastures must receive different management to existing pastures for at least 1 year after sowing to increase their chances of becoming persistent and productive. Long-term monitoring (5-10 years) of new pastures has received little research attention, making assessments of effects of different establishment methods on persistence difficult. Factors likely to affect seedling establishment and plant survival are discussed. Keywords: competition control, cultivation, directdrilling, first year management, Lolium perenne, ryegrass, seedling survival, Trifolium repens, white clover
\end{abstract}

\section{Introduction}

Pasture establishment can be divided into two distinct phases: seed germination and seedling emergence followed by seedling growth and plant survival (Brougham 1969; Cook et al. 1993). This paper focuses on the latter phase and the importance of seedling numbers that develop into mature plants, reflecting the theme of this Symposium. For the purposes of this paper, successful pasture establishment is defined as survival of plants of the sown species (perennial ryegrass (Lolium perenne) and white clover (Trifolium repens), the most important forage sources for grazing animals) for at least 1 year from sowing; this includes survival of the first summer when environmental stress levels (caused by high ambient temperature, low soil moisture, insect attack etc) are high. It is also assumed that certified seed was used, and that for perennial ryegrass, infection levels with viable endophyte are adequate (see Popay \& Hume 2011, this volume).

In an early review of pasture establishment research in New Zealand, R.W. Brougham (Brougham 1969) noted that there were several important areas which had received little or no research, including seedbed preparation, depth of sowing, time of sowing and seed rates. Brougham cited nine papers concerned with lowering the seed rate of the most aggressive species in seed mixtures (usually ryegrass) to allow better establishment of less aggressive species (usually red or white clover).

Bellotti \& Blair (1987) reported that the greatest gap in knowledge of the process of pasture establishment was the survival of the emerged seedlings. Brock \& Thomas (1991) noted that losses of plants (or genotypes, representing each seed sown) ranged from $50-90 \%$ in the year after sowing; with a seed rate of $15 \mathrm{~kg} / \mathrm{ha}$ of ryegrass and $3 \mathrm{~kg} / \mathrm{ha}$ of white clover representing 1000 and 400 seeds (genotypes) $/ \mathrm{m}^{2}$, respectively - this represents a large loss in genetic diversity. Bartholomew et al. (1981) concluded from a comparison of spray and drill, with drilling after cultivation for the establishment of ryegrass, that there was no significant difference in dry matter yield over the 2.5 year trial due to method of establishment, although spray and drill had the lowest yield over the establishment year. Later, when reviewing tillage methods, Bartholomew (2005) concluded that there was "no clear effect of establishment method on persistence", with the caveat that there were few data available. The same researcher (Bartholomew 1973) had already recognised that lack of persistence of pastures was noticeable since about the 1950s in northern Ireland, with little research examining pasture persistence having been published by the 1980s (Charlton \& Thom 1984). There have been few studies since then to close this gap, and none that address the persistence issue when comparing methods of establishment.

There are many methods used to establish pastures in New Zealand and only the main ones will be reviewed here, with emphasis on the recent development of spray and drill technology:

- cultivation

- $\quad$ spray and direct-drill

- undersowing (direct-drilling without killing existing pasture) 
Table 1 Effect of establishment method on survival of new ryegrass plants over 5 years in Waikato dairy pasture. No competition = existing pasture sprayed with glyphosate (1.44 kg a.i./ha) before direct-drilling; Competition = existing pasture undersown (Data from Thom et al. 1993).

\begin{tabular}{lccc}
\hline Time from sowing & Density & (plants $\left./ \mathrm{m}^{2}\right)$ & Signif. \\
\cline { 2 - 3 } & $\begin{array}{c}\text { Competition } \\
\text { (No spray) }\end{array}$ & $\begin{array}{c}\text { No Competition } \\
\text { (Spray) }\end{array}$ & \\
\hline 54 days & 452 & 788 & $* *$ \\
$(15$ May) & & & \\
268 days & 400 & 720 & $*$ \\
$(15$ Dec) & 175 & 400 & $* *$ \\
1 year & 90 & 250 & $* *$ \\
5 years & ** & \\
\hline
\end{tabular}

${ }^{1}$ Date of maximum plant numbers; ${ }^{\star \star}=\mathrm{P}<0.01$

Undersowing involves no seedbed preparation but because it is often used to "patch up" pastures on northern North Island dairy farms, the consequences of this practice will be included in this review.

Oversowing (broadcasting of seed onto the soil surface) (Lambert et al. 1985) is rarely considered by lowland farmers to be a viable method of pasture establishment, and is mainly used to cover bare patches in pasture near gateways, etc. It will not be considered further.

The economics of pasture renewal are also not considered here but the reader is referred to recent publications (Scott et al. 2000; Bryant et al. 2010; Brazendale et al. 2011, this volume) that cover this issue.

\section{Comparisons between establishment methods}

There have been few direct comparisons of pasture establishment methods and subsequent pasture performance, and where monitoring of establishment process has occurred, this has been limited to 2.5 years or less (Bartholomew et al. 1981; Kunelius et al. 1982; Belotti \& Blair 1989 a, b). Presumably, this is because the researchers considered the first few months of the life of the new pasture to be the most important as differences disappeared soon after sowing and/or funding was not available for long-term monitoring.

In the $1950 \mathrm{~s}$ and $1960 \mathrm{~s}$ in New Zealand, undersowing (called overdrilling then) of pastures rather than broadcasting of seed became possible with the development of direct-drilling machines (Cross 1955; Blackmore 1955; 1962). Further developments in coulters and delivery methods for seed and fertiliser plus mechanisms for handling surface litter have increased the success rate of direct-drilling toward that achieved with conventional cultivation (Bartholomew 2005). After reviewing tillage methods, Bartholomew
(2005) confirmed earlier findings that killing or suppressing existing pasture had the greatest influence on emergence, establishment and productivity of the new seedlings drilled into undisturbed seedbeds, but there had been few long-term studies. The objectives of traditional cultivation and tillage methods (ploughing, discing, rolla-tilling, levelling) is to obtain a fine, firm, competition-free, fertile seedbed (Thom et al. 1985; Hume \& Fraser 1985; Triplett \& van Doren 1977). These objectives also apply to the situation where undisturbed seedbeds are to be drilled. However, it is also recognised that environmental conditions are likely to be more critical to the success of direct-drilling compared with conventional cultivation. Doublespraying (initially to kill existing pasture then emerging weed and volunteer seedlings after a fallow period) has ensured unwanted species are eliminated, as well as allowing some moisture conservation in the soil (Hume \& Lyons 1993; Bluett et al. 2004). Such practices are more critical to successful establishment in dryland environments of the slower establishing species such as tall fescue (Festuca arundinacea) (Hume \& Lyons 1993; Milne \& Fraser 1990).

\section{Development of direct-drilling technology}

Baker (1969) argued that "the identification and selection of the most suitable sowing method in a field situation are seldom aided by objective measurements ... the decision coming down to judgement acquired mainly from experience". Research in the 1970s and 1980s assisted farmers in deciding on the most appropriate method. One of the most important messages resulting from this work was that controlling competition from existing pasture plants was essential for successful establishment of new seedlings (Hoveland 1997; Campbell et al. 1987; Cook et al. 1993; Thom et al. 1993). This can be achieved by cultivation or herbicide spraying before direct-drilling into undisturbed soil (Thom et al. 1993; Bartholomew 2005). However, these methods are also the most expensive and so farmers are often attracted to undersowing or directdrilling without killing the existing pasture. Bluett et $a l$. (2004) noted that using herbicides (e.g. glyphosate) before cultivation or direct-drilling was as effective as going through a turnip crop in controlling volunteer seedlings before sowing ryegrass.

The spray and drill technique involves less soil disturbance and probably less carbon loss than does cultivation (Aslam et al. 2000; Baker et al. 2007), although some nitrogen leaching from the breakdown of old pasture may occur (Betteridge et al. 2011, this volume).

In New Zealand, Blackmore (1955), in explaining the advantages of direct-drilling into existing pasture 
(undersowing) over broadcasting seed, conceded that "competition from the existing swards was still a problem" because it has two effects:

- reduced availability of water, nutrients and light to seedlings causing death

- retarded seedling development resulting in weak seedlings unable to cope with stress.

Blackmore suggested mechanical removal of a strip of existing turf before the seed was sown or the use of chemicals to retard growth of the resident species while the new seedlings became established. The use of chemicals such as paraquat to suppress or kill the existing pasture followed (e.g. Vartha 1973; Leonard \& Hart 1977) and by the mid 1970s, glyphosate herbicide was being used in the US, UK, Australia and New Zealand (Wiese 1977; Haggar 1977; Moore 1979; Leonard \& Hart 1977). Both paraquat and glyphosate herbicides had the advantage of being inactivated on soil contact (Leonard \& Hart 1977; Moore 1979). Drill technology also improved, moving to reduced or a competition-free environment for the establishing seedling by banding or blanket spraying of the existing pasture in conjunction with the mechanical action of different coulters fitted to direct-drills (Baker 1980; Baker et al. 1979).

\section{Management factors likely to affect pasture persistence}

\section{Seedling competition with existing pasture plants}

Data in Table 1 from Thom et al. (1993) compare ryegrass persistence over 5 years in a competitionfree environment achieved by spraying with herbicide before drilling or when the new seedlings were subjected to competition from established pasture plants after undersowing. New seedling number was highest 54 days after sowing when $74 \%$ more seedlings were present in sprayed than unsprayed areas. Large losses (greatest in the undersown areas) had occurred by 1 year from sowing as the new plants survived their first summer, but by the end of 5 years, only previously sprayed areas still had a plant density expected of a stable Waikato dairy pasture (200-600 plants $/ \mathrm{m}^{2}$ or $2000-5000$ tillers/m²) (L'Huillier 1987; Thom 1991). Larger coolseason (April-October) DM yields were recorded on average over the 4 years following establishment in the sprayed (4.30 t DM/ha) versus unsprayed (undersown) (3.65 t DM/ha) areas. Differences between sprayed and undersown areas reached significance in Years 1 and 2, and the sprayed treatments achieved the trial aim of removing the summer growing paspalum (Paspalum dilatatum) and introducing more ryegrass to boost seasonal pasture growth in early rather than late lactation.

\section{Drilling depth}

Sowing at a depth of $10-15 \mathrm{~mm}$ is generally accepted as adequate for germination of ryegrass and clover (Bartholomew et al. 1981; Thom et al. 1985; Black et al. 2006). However, Fraser (2008) demonstrated that white clover (sown with ryegrass) germinated best from a depth of 5-10 mm under moist conditions whereas ryegrass germination was satisfactory up to $20 \mathrm{~mm}$ soil depth, suggesting white clover is more sensitive to sowing depth than is ryegrass and its germination might benefit from being sown alone at a shallower depth than that used for ryegrass.

\section{Seed rate and drilling pattern}

It has long been recognised (see Brougham 1969 review) that lowering the seed rate of the most competitive species in seeds mixtures (usually ryegrass) improves the establishment of the less aggressive and slower establishing species (usually white clover). Recent work (e.g. Gerard et al. 2009; Black et al. 2006; Armstrong et al. 2002) supports these conclusions. Black et al. (2006) noted that commonly advocated seed rates for perennial ryegrass of $15-30 \mathrm{~kg} / \mathrm{ha}$ ignores this possibility and is likely to contribute to the generally low white clover contents $(<15 \%$ of DM) of new pastures.

A number of field plot experiments (e.g. Gerard et al. 2009; Praat et al. 1996; Cullen 1958) and early reviews (Blackmore 1955; Cross 1955) have indicated that low seed rates of ryegrass $(6-12 \mathrm{~kg} / \mathrm{ha})$ are sufficient to establish a productive pasture, but as noted above, general seed rate recommendations remain relatively high. This partly reflects the farmers' lack of confidence in seed performance on their farms and extra seed is sown to help compensate for deficiencies in seedbed preparation, dry conditions following sowing, the need to suppress weeds or to improve dry matter yield at the first grazing. No data exist to determine the success or otherwise of this practice but intuitively, applying more seed to a poor situation for seedling germination and survival seems likely to result in more seedling deaths. Weed control, using appropriate herbicides in the first 6 weeks from sowing, is recommended to maintain a competition-free environment for new seedlings; this is especially important if lower seed rates are adopted (6$12 \mathrm{~kg} / \mathrm{ha}$ ), although the suppression effect of high ryegrass seeding rate on weed establishment might be lost in the second year from sowing (Armstrong et al. 2002).

Suppression of weeds during establishment has also been an issue in cultivated seedbeds (Cullen \& Meeklah 1959) so seed rates have been higher when seeds could be distributed evenly over the seedbed using a roller-drill or when broadcast without being drilled. However, when seeds are direct-drilled in rows in autumn or spring, seed rates need to be lowered to 
minimise competition between germinating seedlings competition results in smaller plants (shoots and roots) less able to tolerate stress over summer (Hoen 1968; Thom et al. 1986). Holliday (1953) pointed out that the main benefit of a high seed rate is the extra growth during the first few months after sowing, but then tiller numbers/plant level out regardless of seed rate as high plant mortality with high seed rates is matched by the higher tillering rate of plants sown at lower seed rates. This effect is also reflected in similar DM yields (e.g. Gerard et al. 2009).

Research into the long-term effects of ryegrass seed rate on pasture production and persistence has not been carried out with modern ryegrass cultivars yet the industry recommendations are about $50-100 \%$ higher than previous research plot trials (see above) suggested for a productive, persistent pasture. This trend raises the possibility that for direct-drilled seedbeds, competition between seedlings leads to a large number of small plants (low tiller number and size) that are less tolerant of stress, especially in summer of the establishment year, a situation that could contribute to reduced pasture persistence. This hypothesis will be tested in a series of DairyNZ/AgResearch field trials in Northland, Waikato and Canterbury, commencing autumn 2011 and running to at least 2016.

It is sometimes argued that drilling pattern may lead to a more productive pasture because of advantages in coverage of the exposed seedbed and less opportunity for the establishment of weeds. There has been limited research on drilling patterns but work at Massey University (15 cm row spacings) (Thom \& Ritchie 1993) showed no differences in total DM yield over the year after establishment between single-pass or diamond-drilling (double pass, with the second pass at an angle of 30-45 degrees to the first, and regardless of ryegrass seeding rate- 22 versus $11 \mathrm{~kg}$ seed/ha).

\section{Timing of pasture sowing}

In New Zealand, both autumn and spring sowing of new pastures is carried out. On dairy farms autumn sowing is favoured because it avoids the main growing period of the resident species, and conditions are usually suitable after regular rainfall for the seed germination and seedling growth of the introduced species before the onset of winter (Thom et al. 1985). In colder areas of the South Island early spring sowing is favoured (Blackmore 1955); this is also the case for grasses with slow seedling growth such as tall fescue and white clover (Thom et al. 1985), and red clover (Kunelius et al. 1982) in the lower North Island (e.g., the Manawatu).

\section{Grazing management in the first year after sowing}

Campbell et al. (1987) noted that detailed research on different grazing strategies to promote survival of perennial grasses through summer is scarce. However, since this publication, information on grazing interval relating to leaf regrowth stage, paddock grazing time, pasture tiller dynamics, use of supplements to fill periods of feed deficit and removal of animals during dry periods in summer to minimise overgrazing, have been used to formulate management strategies to assist with pasture persistence (Macdonald et al. 2011, this volume).

Observations suggest that farmers might be misled by the ability of perennial ryegrass seedlings to grow rapidly following germination forming dense lines by about 6 weeks from drilling (especially if seed is drilled according to current industry guidelines at more than 15 $\mathrm{kg} / \mathrm{ha}$ ). This situation may encourage farmers to treat the new pasture like existing pasture before plants have had time to develop a robust root system and overall plant size (tiller number) that will increase summer survival.

Some "rules of thumb" for grazing management of new pastures during the establishment year are suggested to allow emerged seedlings to survive and develop into mature plants. These rules aim to protect the establishing seedlings from excessive damage before they are sufficiently developed to become persistent, productive members of the pasture population.

- Graze new seedlings for the first time when they cannot be "plucked" by hand, usually 5-7 weeks after drilling. Use young stock or cows for a short period (1-2 h).

- Graze when soil conditions are such that no pugging occurs.

- Subsequently, regular grazing is suggested (Brougham 1969) (from a pasture height of 10$15 \mathrm{~cm}$ to a stubble height of $4 \mathrm{~cm}$ ) during the winter/spring following drilling. This encourages ryegrass tillering (increasing size) and prevents shading of establishing white clover seedlings.

- Do not make silage or hay from new pasture in the first spring as this reduces tillering by shading tiller buds and the availability of nutrients for root growth. Tillers formed in December are the basis for the pasture over the next year (Brock \& Thomas 1991), therefore, their survival is important for plant persistence.

- Use small applications of nitrogen (20-25 kg/ha) from 6-8 weeks after drilling to increase seedling size (tiller number) before summer.

- Management of new pastures during the establishment year must be different from that on the remainder of the farm. Consider using stand-off areas and feeding of supplements to reduce pugging damage in winter and overgrazing in summer.

- Do not graze new pastures during periods of stress (e.g. prolonged dry or wet periods). 


\section{Conclusions}

Spray and drill as a method of pasture establishment is as successful as full cultivation provided it is preceded by planning, and appropriate management is applied during the establishment year.

Undersowing existing pasture, although the cheapest option available for introducing new seed, has the greatest risk of failure and if this happens the additional costs of repeated renewal and lost production must be met.

Commonly advocated seed rates for ryegrass conflict with available field plot research results from the 1950s onwards. Trials planned for 2011 will focus on seed rates and whether or not they influence pasture persistence over 5 years or more in contrasting environments (dryland, irrigated, North and South Island), and when rotationally grazed by dairy cows.

Cross- or diamond-drilling is used widely in the dairy industry as a method of controlling weed ingress during early establishment but few trials have examined the effects of this practice on yield and persistence of the resulting pasture.

Grazing strategies in the establishment year require further research, especially as they relate to pasture persistence.

Monitoring of pastures following sowing has received insufficient research attention to ascertain whether or not a particular sowing method is better than another from the point of view of persistence past the establishment year. Such data would greatly assist with farmer choice of establishment method.

\section{REFERENCES}

Armstrong, M.L.; Harrington, K.C.; Seefeldt, S.S. 2002. Weed establishment in the second year after high pasture sowing rates. New Zealand Plant Protection 55: 116-120.

Aslam, T.; Choudhary, M.A.; Saggar, S. 2000. Influence of land-use management on $\mathrm{CO}_{2}$ emissions from a silt loam soil in New Zealand. Agriculture Ecosystems and Environment 77: 257- 262.

Baker, C.J. 1969. The present methods of pasture establishment. Proceedings of the New Zealand Grassland Association 31: 52-59.

Baker, C.J. 1980. Renovation of pastures. Proceedings of the 32nd Ruakura Farmers ' Conference: 53-62.

Baker, C.J.; Thom, E.R.; McKain, W.L. 1979. Development with seed drill coulters for direct drilling IV. Band spraying for suppression of competition during overdrilling. New Zealand Journal of Experimental Agriculture 7: 411-416.

Baker, J.M.; Ochsner, T.E.; Venterea, R.T.; Griffis, T.J. 2007. Tillage and soil carbon sequestration-What do we really know? Agriculture Ecosystems and
Environment 118: 1-5.

Bartholomew, P.W. 1973. Persistency in grasses A review. Internal report 1972-73, Agricultural Research Institute, Northern Ireland, Hillsborough, County Down, 22 pp.

Bartholomew, P.W. 2005. Comparison of conventional and minimum tillage for low-input pasture improvement. Online. Forage and Grazinglands doi: 10. 1094/FG-2005-0913-01-RV.

Bartholomew, P.W.; Easson, D.L.; Chestnut, D.M.B. 1981. A comparison of methods of establishing perennial and Italian ryegrasses. Grass and Forage Science 36: 75-80.

Bellotti, W.D.; Blair, G.J. 1987. The use of sequential measurements of seedling density and seedling size distribution in the evaluation of sowing methods for perennial grasses. pp. 75-78. In: Temperate pastures: their production, use and management. Eds. Wheeler, J.L.; Pearson, C.J.; Robards, G.E. CSIRO, Melbourne.

Bellotti, W.D.; Blair, G.J. 1989a. The influence of sowing method on perennial grass establishment. I. Dry matter yield and botanical composition. Australian Journal of Agricultural Research 40: 301311.

Bellotti, W.D.; Blair, G.J. 1989b. The influence of sowing method on perennial grass establishment. III. Survival and growth of emerged seedlings. Australian Journal of Agricultural Research 40: 323-331.

Betteridge, K.; Crush, J.; Ledgard, S.; Costall, D.; Ouyang, L. 2011. Nitrogen leaching implications of poor pasture persistence. Pasture Persistence. Grassland Research and Practice Series 15: 79-84.

Black, A.D.; Moot, D.J.; Lucas, R.J. 2006. Spring and autumn establishment of Caucasian and white clovers with different sowing rates of perennial ryegrass. Grass and Forage Science 61: 430-441.

Blackmore, L.W. 1955. The overdrilling of pastures. Proceedings of the New Zealand Grassland Association 17: 139-148.

Blackmore, L.W. 1962. Bandspraying: A new overdrilling technique. New Zealand Journal of Agriculture 104: 13-19.

Bluett, S.L.; Thom, E.R.; Dow, B.W.; Burggraaf, V.T.; Hume, D.E.; Davies, E.; Tapper, B.A. 2004. Effects of natural reseeding and establishment method on contamination of novel endophyte-infected perennial ryegrass dairy pasture with other ryegrass/endophyte associations. New Zealand Journal of Agricultural Research 47: 333-344.

Brazendale, R.; Bryant, J.; Lambert, G.; Holmes, C.; Fraser, T. 2011. Pasture persistence: how much is it worth? Pasture Persistence. Grassland Research and Practice Series 15: 3-6. 
Brock, J.L.; Thomas, V.J. 1991. The pasture plant, what is it? Proceedings of the New Zealand Grassland Association 53: 111-116.

Brougham, R.W. 1969. Present position of pasture establishment research in New Zealand. Proceedings of the New Zealand Grassland Association 31: 43-51.

Bryant, J.R.; Lambert, M.G.; Brazendale, R.; Holmes, C.W.; Fraser, T.J. 2010. Effects of integrated cropping and pasture renewal on the performance and profit of dairy farms. Proceedings of the New Zealand Grassland Association 72: 29-34.

Campbell, M.H.; Hosking, W.J.; Nicholas, D.A.; Higgs, E.D.; Read, J.W. 1987. Establishment of perennial pastures. pp. 59-74. In: Temperate pastures: their production use and management. Eds. Wheeler, J.E.; Pearson, C.J.; Robards, G.E. CSIRO, Melbourne.

Charlton, J.F.L.; Thom, E.R. 1984. Establishment and persistence of new herbage species and cultivars. New Zealand Agricultural Science 18: 130-135.

Cross, M.W. 1955. New machines, and methods for oversowing pastures. Proceedings of the Ruakura Farmers' Week, pp. 139-151.

Cook, S.J.; Clem, R.L.; Macleod, N.D.; Walsh, P.A. 1993. Tropical pasture establishment. 7. Sowing methods for pasture establishment in northern Australia. Tropical Grasslands 27: 335-343.

Cullen, N.A. 1958. Pasture establishment studies at Invermay Research Station. Proceedings of the New Zealand Grassland Association 20: 138-147.

Cullen, N.A.; Meeklah, F.A.H. 1959. Seeding rates and weedkillers in pasture weed control. Proceedings of the $12^{\text {th }}$ New Zealand Weed Control Conference: 5459.

Fraser, T.J. 2008. Forage establishment. ForageMasterTM Workshops handbook, pp. 15-22.

Gerard, P.J.; Cooper, B.M.; Eden, T.M.; Howlett, S.A.; Lane, P.S.M.; Pankhurst, K.A.; Willoughby, B.E.; Wilson, D.J. 2009. Impact of ryegrass selection and paddock history on clover establishment in new dairy pasture. Proceedings of the New Zealand Grassland Association 71: 133-137.

Haggar, R.J. 1977. Herbicides and low cost grassland establishment, with special reference to clean seedbeds and one-pass seeding. Proceedings of the International Conference on Energy Conservation in Crop Production, Massey University, Palmerston North, pp. 31-38.

Hoen, K. 1968. The effect of plant size and developmental stage on summer survival of some perennial ryegrasses. Australian Journal of Experimental Agriculture and Animal Husbandry 8: 190-196.

Holliday, R. 1953. Agronomic research in grassland husbandry problems. Agricultural Progress 28: 109123.
Hoveland, C.S. 1997. Problems in establishment and maintenance of mixed swards. Proceedings of the $18^{\text {th }}$ International Grassland Congress 3: 411-416. (source CDRom)

Hume, D.E.; Fraser, T.J. 1985. Establishing and managing recent cultivars in arable dryland pastures. Grassland Research and Practice Series 3: 45-50.

Hume, D.E.; Lyons, T.B. 1993. Methods of establishing tall fescue and ryegrass in a dryland environment. Proceedings of the New Zealand Grassland Association 55: 105-111.

Kunelius, H.T.; Harris, W.; Henderson, J.D.; Baker, C.J. 1982. Comparison of tillage methods on red clover and ryegrass establishment and production under grazing in the establishment year. New Zealand Journal of Experimental Agriculture 10: 253-263.

Lambert, M.G.; Rhodes, A.P.; Barker, D.J.; Bircham, J.S. 1985. Establishing and managing improved plants in hill country. Grassland Research and Practice Series 3: 31-35.

Leonard, W.F.; Hart, R.I.K. 1977. Direct drilling: progress under New Zealand conditions. Proceedings of the International Conference on Energy Conservation in Crop Production, Massey University, Palmerston North, pp. 15-20.

L'Huillier, P.J. 1987. Tiller appearance and death of Lolium perenne in mixed swards grazed by dairy cattle at two stocking rates. New Zealand Journal of Agricultural Research 30: 15-22.

Macdonald, K.A.; Matthew, C.; Glassey, C.B.; McLean, N. 2011. Dairy farm systems to aid persistence. Pasture Persistence. Grassland Research and Practice Series 15: 199-209.

Milne, G.; Fraser, T. 1990. Establishment of 1600 hectares in dryland species around Oamaru/ Timaru. Proceedings of the New Zealand Grassland Association 52: 133-137.

Moore, R.W. 1979. Impact and influence of herbicides on the success of conservation tillage. Proceedings of the Conservation Tillage Technical Seminar, Christchurch, New Zealand.

Popay, A.J.; Hume, D.E. 2011. Endophytes improve ryegrass persistence by controlling insects. Pasture Persistence. Grassland Research and Practice Series 15: 149-156.

Praat, J-P.; Ritchie, W.R.; Baker, C.J.; Hodgson, J. 1996. Target populations for direct-drilled ryegrass and tall fescue. Proceedings of the New Zealand Grassland Association 57: 77-81.

Scott, J.F.; Lodge, G.M.; McCormick, L.H. 2000. Economics of increasing the persistence of sown pastures: costs, stocking rate and cash flow. Australian Journal of Experimental Agriculture 40: 313-323.

Thom, E.R. 1991. Effect of early spring grazing 
frequency on the reproductive growth and development of a perennial ryegrass tiller population. New Zealand Journal of Agricultural Research 34: 383-389.

Thom, E.R.; Ritchie, W.R. 1993. Banded versus blanket spraying and drilling pattern. pp. 55-58. In: Pasture renovation manual. Eds. Pottinger, R.P.; Lane, P.S.M.; Wilkins, J.R. New Zealand Pastoral Agriculture Research Institute Ltd.

Thom, E.R.; Thomson, N.A.; Clayton, D.G. 1985. Establishment and management of suitable species in dairy pastures. Grassland Research and Practice Series 3: 71-75.

Thom, E.R.; Sheath, G.W.; Bryant, A.M.; Cox, N.R. 1986. Renovation of pastures containing paspalum 3. Effect of defoliation management and irrigation on ryegrass growth and persistence. New Zealand Journal of Agricultural Research 29: 599-611.
Thom, E.R.; Wildermoth, D.D.; Taylor, M.J. 1993. Growth and persistence of perennial ryegrass and white clover direct-drilled into a paspalum-dominant dairy pasture treated with glyphosate. New Zealand Journal of Agricultural Research 36: 197-207.

Triplett, G.B.; van Doren, D.M. 1977. Agriculture without tillage. Scientific American 236: 28-35.

Vartha, E.W. 1973. Herbage production from overdrilled pasture in Canterbury. Proceedings of the New Zealand Grassland Association 34 (Part 2): 177-184.

Wiese, A.F. 1977. Limited tillage in the U.S.A. Proceedings of the International Conference on Energy Conservation in Crop Production, pp. 21-30. 
